\title{
Asian corn borer (Ostrinia furnacalis Guenee) oviposition preferences on maize (Zea mays Linn), king grass (Panicum maximum Jacq.), and cogon grass (Imperata cylindrica (L.)
}

\author{
Preferensi oviposisi penggerek batang jagung (Ostrinia furnacalis \\ Guenee) pada tanaman jagung (Zea mays Linn), rumput raja \\ (Panicum maximum Jacq.), dan alang-alang (Imperata cylindrica (L.)
}

\author{
Yosefus F. da-Lopez ${ }^{1}$, Y. Andi Trisyono², Witjaksono ${ }^{2}$ \\ ${ }^{1}$ Jurusan Manajemen Pertanian Lahan Kering, Politeknik Pertanian Negeri Kupang \\ Jalan Adisucipto Penfui PO. Box 1152, Kupang Nusa Tenggara Timur 85011 \\ ${ }^{2}$ Jurusan Jurusan Hama dan Penyakit Tumbuhan, Fakultas Pertanian, Universitas Gadjah Mada \\ Jalan Flora No.1 Bulaksumur, Yogyakarta 55281
}

(diterima Juli 2019, disetujui Maret 2020)

\begin{abstract}
Insects' oviposition behavior on alternate host plants is very helpful to understand the interaction between host plants and insects, the dynamics of insect populations, and the effectiveness of alternate host plants as refugia in managing insect resistance. The oviposition preference of Ostrinia furnacalis on maize (Zea mays L), king grass (Panicum maximum Jacq.), and cogon grass (Imperata cylindrica (L.) was studied through no-choice test, two-choice test, and three-choice test. The oviposition preferences hierarchy of $O$. furnacalis on maize, king grass, and cogon grass wass sequentially maize $>$ king grass $>$ cogon grass when the tested plants were at 21 DAP (days after planting). However, the hierarchy pattern may change depending on host plants phenology. The 35-day-old king grass was more preferred by $O$. furnacalis (proportion of eggs $=0.692$; OPI $=37.57$ ) than maize (proportion of eggs $=0.301$; OPI $=-38.780$ ) and cogon grass (proportion of eggs $=0.174$; OPI $=-65.183$ ) for oviposition. These findings indicated that king grass was a potential alternate host for $O$. furnacalis to survive and could serve as refugia in IRM strategy. However, it needs further research in the field to ensure the potential of king grass as refugia for $O$. furnacalis.
\end{abstract}

Key words: Imperata cylindrica L., Ostrinia furnacalis, oviposition, Panicum maximum Jacq., Zea mays L.

\begin{abstract}
ABSTRAK
Perilaku oviposisi serangga pada tanaman inang alternatif sangat membantu untuk memahami interaksi antara tanaman inang dan serangga, dinamika populasi serangga, dan efektivitas inang alternatif sebagai refugia dalam mengelola resistensi serangga. Preferensi oviposisi Ostrinia furnacalis Guenee pada jagung (Zea mays L), rumput raja (Panicum maksimum Jacq.), dan alang-alang (Imperata cylindrica (L.) dikaji melalui uji preferensi dengan uji tanpa-pilihan, uji dua-pilihan, dan uji tigapilihan. Hirarki preferensi oviposisi dari $O$. furnacalis pada tanaman jagung, rumput raja, dan alangalang adalah jagung $>$ rumput raja $>$ alang-alang ketika tanaman yang diuji berumur 21 hari. Hirarki preferensi oviposisi tersebut dapat berubah bergantung pada fenologi tanaman inang. Rumput raja
\end{abstract}

\footnotetext{
*Penulis korespondensi: Yosefus F. da-Lopez. Jurusan Manajemen Pertanian Lahan Kering, Politeknik Pertanian Negeri Kupang Jalan Adisucipto Penfui, PO. Box 1152, Kupang Nusa Tenggara Timur 85011. Tel: (0380) 881600, Faks: (0380) 881601,

Email: yosdapisco@gmail.com; yosefus.lopez@staff.politanikoe.ac.id
} 
berumur 35 hari lebih disukai oleh $O$. furnacalis untuk oviposisi (proporsi jumlah telur =0,692; OPI $=37,57$ ) daripada jagung (proporsi jumlah telur $=0,301$; OPI $=-38,780$ ) dan alang-alang (proporsi jumlah telur $=0,174$; OPI $=-65,183$ ) pada umur yang sama. Hasil ini menunjukkan bahwa rumput raja merupakan inang alternatif yang potensial bagi $O$. furnacalis untuk bertahan hidup dan dapat berfungsi sebagai refugia dalam strategi manajemen resistensi serangga.

Kata kunci: Imperata cylindrica L., Ostrinia furnacalis, oviposisi, Panicum maximum Jacq., Zea mays L.

\section{INTRODUCTION}

Common problem in the cultivation of maize is the Asian Corn Borer, Ostrinia furnacalis (Guenée, 1854 syn. Botys damoalis Walker) (Lepidoptera: Crambidae). This insect can damage the maize up to $98 \%$ (Abdullah \& Rauf 2011) and yield loss was approximately 18-80\% (Ceballo \& Rejesus 1983; Nonci et al. 1996). This led to the high use of insecticides and increased the risk of insect resistance to insecticides. Insect resistance and lack of new insecticides invention become a major threat to agricultural productivity and may increase the costs in agricultural production (Trisyono 2001). Variability levels of vulnerable populations in the fields may increase the opportunity of insects to develop resistancy. A strategy for IRM can be implemented by delaying resistance development (Trisyono 2001; Head 2004; Bates et al. 2005; Caasi-Lit 2006; Tabashnik et al. 2003 \& 2010). This strategy can be achieved through high-doses of refugia according to the philosophy of IRM requirements to maintain susceptible alleles in refugia with a minimum economic damage (Bates et al. 2005).

Insect-tolerant varieties that sustain to herbivores can be employed as refugia (Smith 2012), such as wild plants or weeds. Those plants can be applied to address the resistance development of $O$. furnacalis (Caasi-Lit 2006; Tabashnik 2003). This strategy may allow mating between resistant insects in the main host plants or transgenic plants and susceptible insects in refugia. It may produce recessive-alleles offsprings. These offsprings are vulnerable and may be eliminated in crops exposed to insecticides or in transgenic plants. Eventually, the evolution of resistance development can be reduced (Trisyono 2001; Head 2004; Bates et al. 2005; Caasi-Lit 2006; Tabashnik et al. 2003, 2010). Several conditions including concentration of toxins, resistant alleles as well as the movement of adults and synchronization of adult emergence must be considered to ensure the effectiveness of high-doses/refugia strategy (Trisyono 2001). Studying on O. furnacalis oviposition behavior on alternate host plants is needed to understand the interactions between host plants and insect population dynamics, and the effectiveness of the alternate host plants as refugia in designing appropriate refugia programs. The function of alternate host plants as refugia or a shelter and breeding place may reduce the possibility of insect population to build up.

King grass and cogon grass can be used as alternate host for $O$. furnacalis (Caasi-Lit 2006). These plants are relatively similar to maize in its morphology (Jacobs 2012; Horticulture and Crop Science at The Ohio State University 2012) and nutrient content (Soepardi 1986; Duke 2012; Hartadi et al. 1983; Hartemink 2001, 2002). The presence of host plants is needed by female insects as a place to lay eggs and as a food source for larvae to survive. This study was to investigate the oviposition preferences of $O$. furnacalis on king grass and cogon grass as alternate hosts for $O$. furnacalis. The suitability of these alternate host plants as refugia for $O$. furnacalis can be useful in developing an IRM strategy. Refugia plants can also provide shelter, food sources or other resources for natural enemies such as predators and parasitoids (Nentwig 1998; Wratten et al. 1998 cit. Allifah et al. 2013). Therefore, it may contribute to the conservation of natural enemies in biological pest control.

\section{MATERIALS AND METHODS}

\section{Host plants and experimental conditions}

The study used three host plants: cogon grass, king grass, and maize at 21 and 35 days after planting (DAP). These three host plants 
were germinated in pots and moved into $50 \mathrm{~cm} \mathrm{x}$ $50 \mathrm{~cm} \mathrm{x} 75 \mathrm{~cm}$ of cages to be studied. The pots were black plastic pots, $20 \mathrm{~cm}$ in diameters, and the cages were rectangular shaped cages with wooden frame and white gauze walls. The arrangement of the host plants in cages based on preference tests i.e. no-choice, two-choice, and three-choice tests designed in completely randomized design.

\section{Insects and measures of oviposition preference}

Eggs and larva of $O$. furnacalis were collected from the fields in Yogyakarta and mass-rared in the Pesticide Toxicology Laboratory, Department of Crop Protection, Faculty of Agriculture, UGM, using the laboratory-made artificial diet, at a temperature of $28.93 \pm 0.91{ }^{\circ} \mathrm{C}$ and a humidity of $74.11 \pm 6.48 \%$. The temperature and humidity in the laboratory were suitable for $O$. furnacalis to grow and develop. Newly hatched first instar larvae were mass-reared until they molted to the second instar. After moulting to the third instar, these newly moulted larvae were placed individually in plastic bottles $(5 \mathrm{~cm}$ in height, $4 \mathrm{~cm}$ in diamater) and fed using laboratory-made artificial diet until pupation. The artificial diet consisted of 100 grams of red beans, 4 grams of niphagine, 5 grams of ascorbic acid, 5 grams of sorbic acid, 32 grams of yeast, 110 grams of rice bran, 30 grams of agar, and $450 \mathrm{ml}$ of water. Ten pupae at the same age were placed in the $50 \mathrm{~cm} \times 50 \mathrm{~cm} \times 75 \mathrm{~cm}$ of cages, with a 4:6-sex ratio of males to females.

Numbers of egg-masses laid on the host plant surfaces and cage screens were counted and then used to understand the oviposition preference using two parameters i.e. the proportion of egg-masses laid on the surfaces of host plant (Greenberg et al. 2001) and oviposition preference index (Grant \& Langevin 1995). The number of egg-masses were counted in this study to know the total number of eggs laid so the proportion of eggs be calculated. Proportion value of $>0.5$ indicates that the host plants were attractive for oviposition (Greenberg et al. 2001). Oviposition preference index (OPI) was based on Grant \& Langevin (1995):

$$
\text { OPI }=[(\mathrm{T}-\mathrm{C})) /((\mathrm{T}+\mathrm{C})] \times 100, \text { in which }
$$

$\mathrm{T}$ : the total number of egg-masses laid on the surface of host plants; C: the total number of eggmasses laid on the control (the maize placed in a cage without any other plants to choose). The value of oviposition preference index ranges from -100 to 100 . Negative value indicates oviposition deterrence and positive value indicates stimulation.

No-choice test. This test was performed to investigate whether females of $O$. furnacalis would lay eggs on experimental host plants if there was no other host plant to choose. To examine the oviposition preference, each 21 DAP of king grass, cogon grass, and maize was put separately in a cage of $50 \mathrm{~cm} \times 50 \mathrm{~cm} \times 75 \mathrm{~cm}$ and placed in the greenhouse. Each cage contained two pots, one plant per pot, and 10 pupae with a 4:6-sex ratio of males to females. Three replications were in each treatment. The newly emerged females and males were allowed to mate and to oviposit until all of females died. Three cups, each containing a cotton ball soaked with $10 \%$ sucrose, were placed on the upper side of each cage for adults feeding. The number of egg-masses laid on each host plant surface and cage was recorded daily, starting two days after the adults (females) emerged from the pupae.

Two-choice test. Three different host plant species aged 35 days were paired in three possible combinations, king grass vs. cogon grass, king grass vs. maize, and cogon grass vs. maize. Each possible combination consisting of two different host plant species was arranged in a cage of $50 \mathrm{~cm}$ $\times 50 \mathrm{~cm} \times 75 \mathrm{~cm}$ and placed in a greenhouse. Each cage contained four pots ( 2 pots per each host plant species, 1 plant per pot) and 10 pupae with a 4:6sex ratio of males to females. The newly emerged females and males were allowed to mate and to oviposit until all of females died or \pm 7 after being released into the cages. Cups containing a cotton ball soaked with $10 \%$ sucrose (Tropicana Slim Madu 350MG), were placed on the upper side of each cage to feed the adults. The number of eggmasses laid on each host plant surface and cage by females was recorded daily, starting two days after the adults (females) emerged from the pupae.

Three-choice test. Ten pupae with a 4:6-sex ratio of males to females, together with three different species of 21-day-old host plants were put stimuneously in one cage. Each cage contained three potted host plants, a pot with a single host plant species. Observation on the number of 
egg-masses laid was conducted using the same procedures in the previous tests.

\section{Statistical analysis}

One-way ANOVA and independent $t$-test were used to analyze proportions of eggs and to oviposition preferences index in no-choice test and three-choice test whether significant influence among the host plants existed. When experiments were repeated, the homogeneity of variance of the individual experiments was tested before pooling data. If there were no differences, the experiments were pooled. When significant $\mathrm{F}$-values were obtained, means were separated using Turkey's HSD test in the case of no-choice and threechoice tests. In the two-choice test, means of eggs proportion and oviposition preference index were analized using independent $t$-tests. Proportion data were arcsine-square root transformed before being analyzed statistically. Results appearing in the text and tables were presented as back-transformed data. The oviposition preference index (Grant \& Langevin 1995) was considered significantly different from zero if the $95 \%$ confidence interval do not span zero.

\section{RESULTS}

\section{No-choice test}

There was significant influence of the host plants tested to the proportion of the number of egg-masses $(\mathrm{F}=27.85, \mathrm{df}=2 ; \mathrm{p}=0.001)$ and oviposition preference index $(\mathrm{F}=27.85, \mathrm{df}=2 ; \mathrm{p}$ $=0.001, \mathrm{n}=3)$. Since the proportion value is above 0.5 (Fig. 1A) with oviposition preference index of $>0$ or positive (Fig. 1B), it indicates that king grass and cogon grass were attractive to $O$. furnacalis to oviposit even though their preferences were lower than those on maize. The proportion of eggmasses laid on king grass (0.731) was significantly higher than on cogon grass $(0.60)(\mathrm{p}=0.040)$ but lower than on maize $(0.90)(\mathrm{p}=0.014)$ (Fig. 1A). Oviposition preference index on king grass (46.17) was significantly higher than on cogon grass $(19.94)(p=0.040)$ but lower than on maize (80.05) $(\mathrm{p}=0.014)($ Fig. 1B).

\section{Two-choice test}

Females of $O$. furnacalis preferred to lay eggmasses on maize and king grass than on cogon grass (Fig. 2). When king grass was paired with cogon grass (combination I), the proportion of eggmasses laid on king grass $(0.826)$ was significantly higher than on cogon grass $(0.174)(t=13.911, \mathrm{df}=$ $8, \mathrm{p}<0.001 ; \mathrm{n}=5$ ) (Fig. 2A). Similarly, when king grass was paired with maize (combination II), the proportion on king grass $(0.692)$ was significantly higher than on maize $(0.306)(t=5.484, \mathrm{df}=10 ; \mathrm{p}<$ $0.001, \mathrm{n}=6$ ) (Fig. 2A) but when maize was paired with cogon grass (combination III), the proportion on maize $(0.760)$ turned to be significantly higher than on cogon grass $(0.155)(t=12.837, \mathrm{df}=12 ; \mathrm{p}$ $<0.001, \mathrm{n}=7$ ) (Fig. 2A). There was no significant

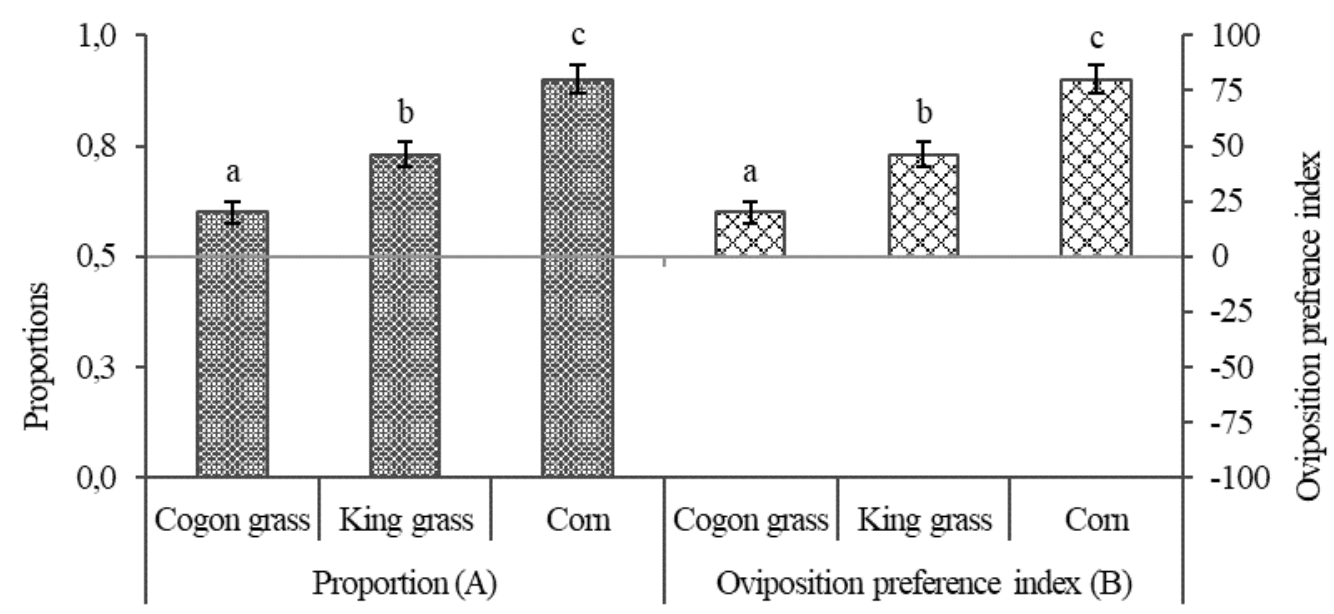

圈 Proportions of the number of eggs Oviposition preference index

Figure 1. Mean $( \pm \mathrm{SE})$ proportions and oviposition preference index of the total number of Ostrinia furnacalis egg-masses laid on the surfaces of host plants tested in no-choice tests. Means accompanied by the same lowercase letters are not significantly different ( $p<0.05$; Tukey's HSD). 
difference in the proportion of egg-masses laid on king grass (0.692) paired with maize (combination II) and on king grass (0.826) paired with cogon grass (combination I) $(t=2.171, \mathrm{df}=9 ; \mathrm{p}=$ $0.058)$. Meanwhile, the proportion of egg-masses laid on maize $(0.760)$ paired with cogon grass (combination III) was significantly higher than on maize (0.301) paired with king grass (combination II) $(t=7.471, \mathrm{df}=11 ; \mathrm{p}<0.001)$ (Fig. 2A). Oviposition preference index on cogon grass (Fig. 2B) was significantly lower than on all host plants paired with, either with maize (combination III) $(t=12.837, \mathrm{df}=12 ; \mathrm{p}<0.001)$ or with king grass (combination I) $(t=13.911$, df $=8 ; \mathrm{p}<$ $0.001)$. King grass significantly performed higher oviposition preference index than all host plant paired with, either with maize (combination II) ( $t$ $=5.484, \mathrm{df}=10 ; \mathrm{p}<0.001)$ or with cogon grass (combination I) $(t=13.911, \mathrm{df}=8 ; \mathrm{p}<0.001)$. No significant difference was found in the oviposition preference index on king grass in combination I and II ( $t=2.171, \mathrm{df}=9 ; \mathrm{p}=0.058)$ (Fig. 2B).

Oviposition on king grass with the proportion of $>0.5$ (Fig. 2A) and oviposition preference index of $>0$ or positive (Fig. 2B) means that when a preferred king grass exists, females of $O$. furnacalis will choose grass king for oviposition than maize and cogon grass. These results indicate that the interaction between the host plant species affect the behavior of females in choosing a host plant for oviposition.

\section{Three-choice test}

The experimental host plants significantly affected the proportion of the number of eggmasses $(\mathrm{F}=19.306, \mathrm{df}=2 ; \mathrm{p}<0.001, \mathrm{n}=5)$ and oviposition preference index $(\mathrm{F}=19.306, \mathrm{df}=2 ; \mathrm{p}$ $<0.001$ ) when females of $O$. furnacalis were given to choose among three host plants. Both king grass and cogon grass performed the proportion of $<$ 0.5 (Fig. 3A) with oviposition preference index was negative or $<0$ (Fig. 3B). It shows that in the presence of maize together with king grass and cogon grass, females of $O$. furnacalis would prefer to choose maize for oviposition than the two other plants. However, as shown in Figure 2, the response of females for oviposition on king grass can be positive if a suitably developmental stage of king grass is available. The proportion of eggmasses laid on maize (0.569) was significantly higher than on king grass $(0.248)(\mathrm{p}=0.003)$ and cogon grass $(0.123)(\mathrm{p}<0.001)$ (Fig. 3A) while the

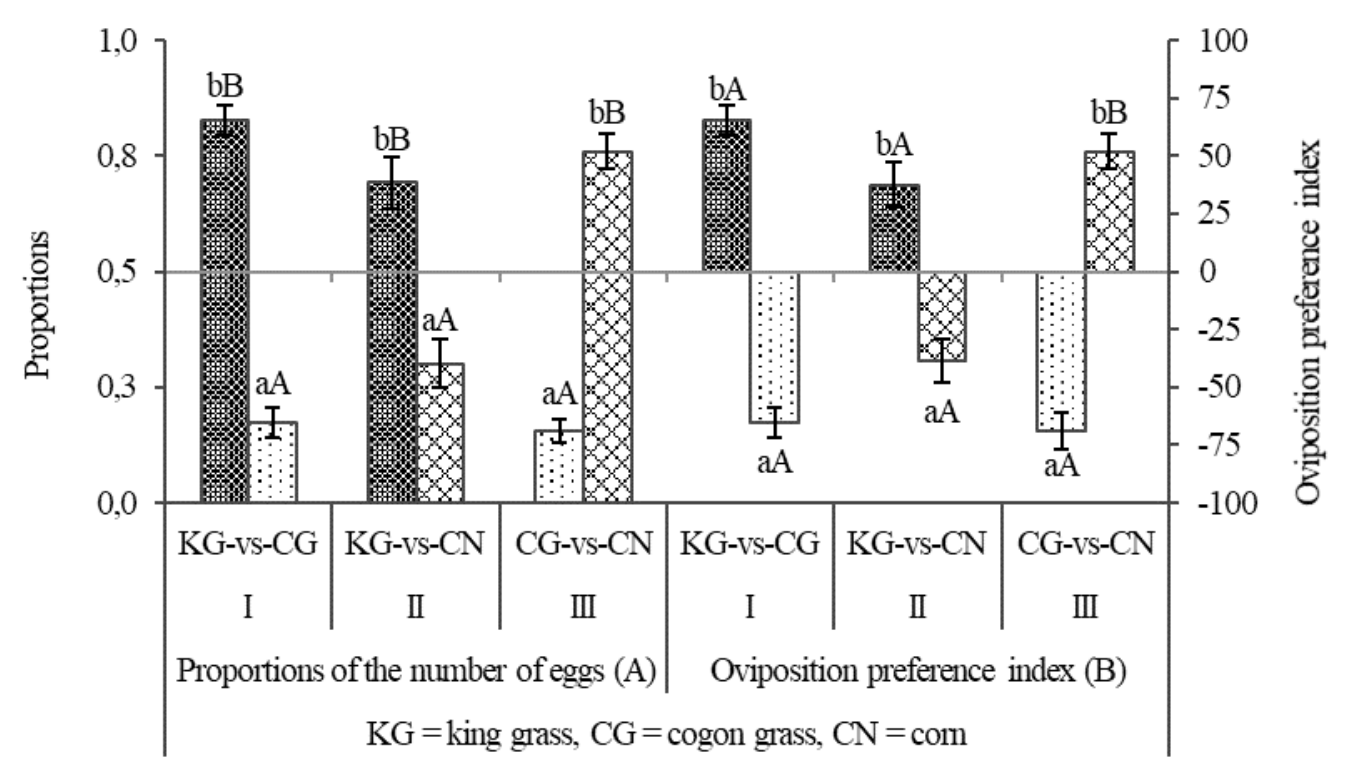

Figure 2. Mean $( \pm \mathrm{SE})$ proportions oviposition preference index of the total number of Ostrinia furnacalis egg-masses laid on the surfaces of host plants tested in two-choice tests. Means accompanied by the same lowercase letters are not significantly different $(\mathrm{p}>0.05$; independent samples $t$-test) between host plant in each combination and means accompanied by the same uppercase letters are not significantly different $(\mathrm{p}>0.05$; independent samples $t$-test) for the same host plants between combinations. 
oviposition preference index on maize (13.704) was significantly higher than on king grass $(\mathrm{p}=$ 0.003 ) and cogon grass $(\mathrm{p}<0.001)$ (Fig. 3B).

This study also found that females of $O$. furnacalis not only oviposited on the surfaces of host plants but also on the cages screen (Table 1). There was no significant difference in the number of egg-masses laid on cogon grass and on the cage screen $(t=2.897, \mathrm{df}=4 ; \mathrm{p}=0.044)$ while the number of egg-masses laid on king grass and maize was significantly higher than those laid on cage screen of king grass $(t=12.978, \mathrm{df}=4 ; \mathrm{p}<$ $0.001)$ and maize $(t=12.636, \mathrm{df}=4 ; \mathrm{p}<0.001)$. There was no significant difference in the number of egg-masses laid on cogon grass cage screen compared to those laid on king grass cage screen $(\mathrm{p}=0.157)$, but it was significantly different with those on maize cage screen $(\mathrm{p}<0.05)$. These results indicate stimulation for $O$. furnacalis to lay egg-masses on cogon grass and king grass.

\section{DISCUSSION}

A number of gramineous crops, such as maize, contains cyclic hydroxamic acid that is toxic to most herbivores but $O$. furnacalis is one of insects that uses maize because this insect has enzymatic adaptation to the chemical compound (Calas 2007;
Kojima et al. 2010). Some plants and weeds, such as king grass and cogon grass, have been known to be the potential host plants which can serve as natural refugia for $O$. furnacalis. This study clearly documented oviposition preference in these two alternate host plants (king grass and cogon grass). The females tended to oviposit on host plants tested than on cage screen when only one host plant was given to choose and performed significantly different in the eggs proportion and oviposition preference index. This indicates that the cues from these host plants are not only stimulating but also attractive for oviposition. However, it seems that cogon grass tended to be neutral or slightly attractive for oviposition.

When an option was given to the three host plants, the proportion of the total number of eggmasses laid on maize was the highest (above $0.5)$ with positive oviposition preference index and then followed by king grass and cogon grass which were less attractive for oviposition. If the proportion and oviposition preference index in nochoice test compared to those in two-choice test and three-choice test, the different perceptions of females for oviposition on each host plant species existed. The perception of females on cogon grass in the context of no other host plant to choose turned to be negative in the presence of king grass or maize, or both. This response may be due to the

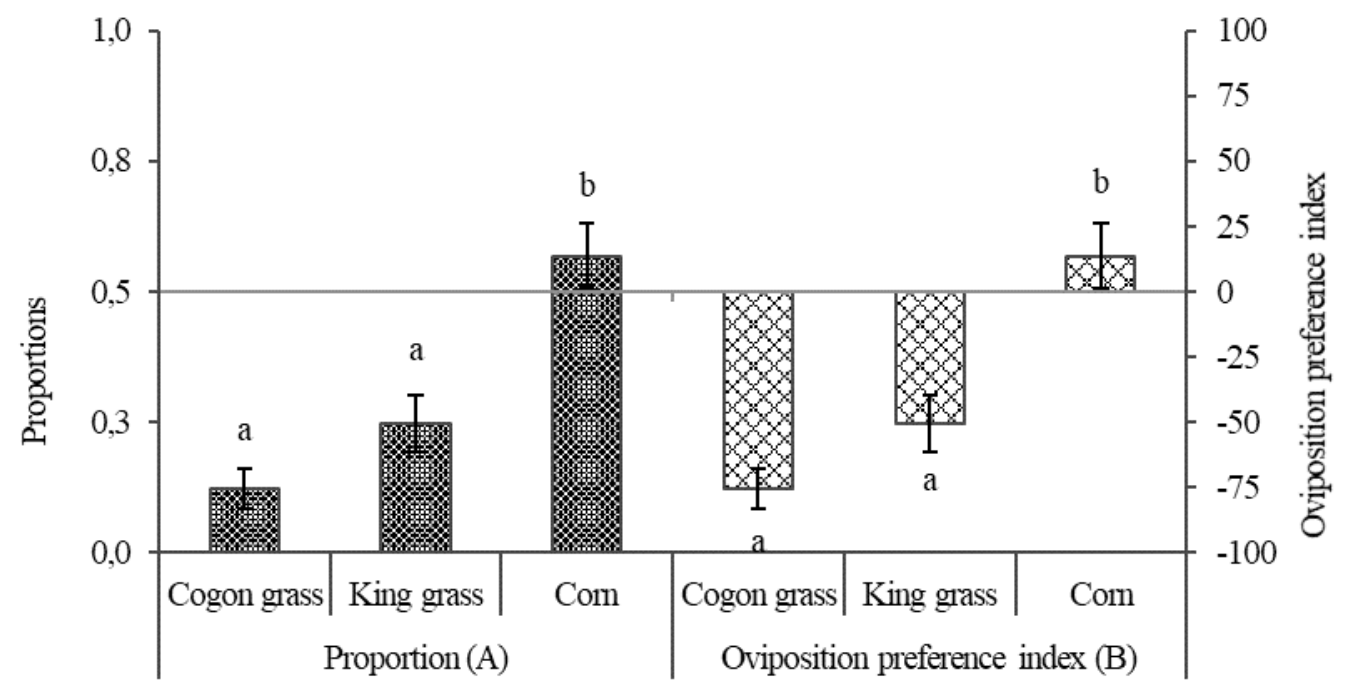

Proportions of the number of eggs $\quad$ Oviposition preference index

Figure 3. Mean $( \pm \mathrm{SE})$ proportions and oviposition preference index of the total number of Ostrinia furnacalis egg-masses laid on the surfaces of host plants tested in three-choice tests. Means accompanied by the same lowercase letters are not significantly different ( $p<0.05$; Tukey's HSD). 
Table 1. The average number of Ostrinia furnacalis egg-masses laid on cage screen and host plants in nochoice test

\begin{tabular}{lcc}
\hline \multirow{2}{*}{ Host plant species } & \multicolumn{2}{c}{ Number of egg-masses (mean \pm SE) } \\
\cline { 2 - 3 } & On cage screen & On host plant \\
\hline Cogon grass & $20,67 \pm 1,20 \mathrm{bA}$ & $31,33 \pm 3,48 \mathrm{aA}$ \\
King grass & $15,67 \pm 1,86 \mathrm{bA}$ & $42,33 \pm 0,88 \mathrm{abB}$ \\
Maize & $5,67 \pm 1,76 \mathrm{aA}$ & $52,00 \pm 3,21 \mathrm{bB}$ \\
\hline
\end{tabular}

Mean values accompanied by the same lowercase letters in each row in the same column are not significantly different $(\mathrm{p}>$ 0.05 , Tukey's HSD), whereas mean followed by the same uppercase letters in each column in the same row are not significantly different $(\mathrm{p}>0.05$, independent samples $t$-Test).

more powerful cues given off by king grass and maize. Cogon grass has been known to have silicon (Soepardi 1986; Hartadi et al. 1983; Hartemink 2001 \& 2002; Reynolds et al. 2009). This may cause the rejection of this plant by females of $O$. furnacalis for oviposition.

The nature or type of cues of host plants recognized by females is still unknown for certain, but it may be because of the chemical, tactile, and visual cues, or combination of them (Bernays \& Chapman 1994). The differences in the oviposition response to an isolated host plants compared to the rest of the plants showed that tactile cues are less important than chemical or visual cues. In finding their host plants, an insect might encounter plant-related chemical stimuli, starting with the detection of volatiles at a distance (Bernays \& Chapman 1994). Thus, the movement of females in finding a preferred host plant for oviposition due to chemical cues is more influential than tactile and visual cues. However, this assumption needs further investigation over an experiment, which is designed, especially, to determine the importance of cues that potentially affect to oviposition preference in different contexts.

Selection of host plants by female insects is an adaptation behavior to locate their offsprings in a suitable host plant. The size of egg-masses also depends on the individual host plant species, following the same hierarchy with the preferences for host plants (Greenberg et al. 2001). It can be modified to reflect compliance with the host plants for oviposition. This study found that the size of egg-masses laid on cogon grass are generally smaller (with 1-2 narrow lines of egg-mass) than those in king grass and maize (with 3-5 wide lines of egg-mass). Various size and shape of eggs-dependent host plants have been reported in other insects (Greenberg et al. 2001; Grant \& Langevin 1995; van Leerdam et. al. 1984). Other experiment on the growth and development of larval $O$. furnacalis showed that the newly hatched first instar larva only survive 2-3 days feeding on cogon grass leaves compared to those feeding on king grass and maize leaves that can survive until newly moulted third instar larva reached. When the third instar larvae fed on stems of king grass, the weight of the fifth instar larva was significantly lower $(68 \mathrm{mg})$ than those on maize $(82 \mathrm{mg})$ with $20 \%$ inhibition value of larval weight, the size of pupae and adults were also smaller in body size. It seems that oviposition preference of females is also related to the potency of nutritional value of the host plants.

The age or developmental stage of host plants may affect oviposition preference of $O$. furnacalis. When 21 DAP king grass was used, a negatifve oviposition preference found in three-choice test turned to be positive when king grass was 35 DAP. In other cases, when 14 DAP maize was paired with 35 DAP cogon grass, it was found that females preferred to oviposit on cage screen than on plant surface. It might be due to the high level of DIMBOA in maize and the presence of silicon in cogon grass (Soepardi 1986; Hartadi et al. 1983; Hartemink 2001 \& 2002; Reynolds et al. 2009) which is not found in both king grass and maize (Duke 2012; Peplinski et al. 1989).

The concentration of DIMBOA is high in the early growth and turns to decline in line with the the age of maize (Yan et al. 1999). Numerous studies suggested that silicon can enhance host plant resistance to herbivore insects, including folivory and stem borers that directly impact the performance of insects and indirectly cause the decrease in the number of insects and crop 
damage (Reynolds et al. 2009). Deposition of silica, especially as phytoliths opaline, mediates plant defense involving reduced digestibility and/ or increased hardness and abrasiveness of plant tissue (Reynolds et al. 2009).

These results suggest that the perception of females on cogon grass, king grass, and maize, in specified cases, may be either positive or negative through the interaction of cues of at least two host plants tested (Greenberg et al. 2001). The quality of host plants, such as age and phenology, developmental stage and time of planting may be the factors influencing oviposition, in addition to climatic factors and habitat (Calas et al. 2007). The age and plant phenology may affect the nutritional concentration and the contents of secondary chemical compounds. The nutritional and secondary metabolites concentrations may be changed through the age and plants phenology but the assumption regarding the influence of age and plant phenology on oviposition preference needs to be more investigated. Several compounds on the surface of plant leaves, such as glucose (Bas et al. 2008), pentane extracts of plants (Bas et al. 2008; Udayagiri \& Mason 1995), and volatile sesqueterpenoids farnesene (Binder et al. 1995) can stimulate oviposition. While, larval feces and damaged plants emit volatile (such as palmitic acid, stearic acid, oleic acid, linoleic acid and linolenic acid) that may repel gravid females by avoiding oviposition (Bas et al. 2008; Li \& Ishikawa 2004). The presence of farnesol also provides deterrence to females for oviposition (Binder et al. 1995).

In conclusion, it was found that $O$. furnacalis more attractive to king grass as alternative host plant than cogon grass. It indicates that king grass can be utilized as a trap or barrier plant for $O$. furnacalis to lay eggs directly on maize. The attraction of $O$. furnacalis may change depending on the interaction of the host plant with other plant and the condition of plants phenology. These results will be benefit for IPM decision-making or in IRM strategy. However, for IRM strategy, a further research is needed to prove that king grass actually can be used by $O$. furnacalis to develop and survive.

\section{ACKNOWLEDGMENT}

We acknowledge the technical assistants: Sriyanto Haryanto and A. Hendracipta for assisting our works in laboratory and the procurement of host plants, artificial diet, and eggs of $O$. furnacalis. We are also thankful to the Direktorat Jenderal Pendidikan Tinggi for the research funding.

\section{CONCLUTION}

The oviposition preferences hierarchy of $O$. furnacalis on maize, king grass, and cogon grass was sequentially maize $>$ king grass $>$ cogon grass when the tested plants were at 21 DAP (days after planting). However, the hierarchy pattern may change depending on host plants phenology. The 35-day-old king grass was more preferred by O. furnacalis (proportion of eggs $=0.692$; OPI $=$ 37.57) than maize (proportion of eggs $=0.301$; OPI $=-38.780$ ) and cogon grass (proportion of eggs $=0.174$; OPI $=-65.183$ ) for oviposition. These findings indicated that king grass was a potential alternate host for $O$. furnacalis to survive and could serve as refugia in IRM strategy. However, it needs further research in the field to ensure the potential of king grass as refugia for $O$. furnacalis.

\section{REFERENCES}

Abdullah T, Rauf A. 2011. Karakteristik populasi dan serangan penggerek jagung asia, Ostrinia furnacalis (Lepidoptera: Pyralidae), dan hubungannya dengan kehilangan hasil. Jurnal Fitomedika 7:175-181.

Allifah ANAF, Yanuwiad B, Gama ZP, Leksono AS. 2013. Refugia sebagai Mikrohabitat untuk Meningkatkan Peran Musuh Alami di Lahan pertanian. In: Prosiding FMIPA Universitas Pattimura, (Ambon, 26 Maret 2013). pp. 113116. Ambon: Universitas Patimura.

Bas PS, Dutton A, Bigler F, Van Lenteren JC. 2008. Oviposition behaviour and egg distribution of the European corn borer, Ostrinia nubilalis, on maize, and its effect on host finding by Trichogramma egg parasitoids. Bulletin of Insectology 61:303-312.

Bates SL, Jian-Zhou Z, Roush RT, Shelton AM. 2005. Insect resistance management in GM crops: Past, 
present and future. Nature Biotechnology 23:5762. doi: https://doi.org/10.1038/nbt1056.

Bernays EA, Chapman RF. 1994. Host-Plant Selection by Phytophagous Insects. Contemporary Topics in Entomology 2. New York: Chapman and Hall. doi: https://doi.org/10.1007/b102508.

Binder BF, Robbins JC, Wilson RL. 1995. Chemically mediated ovipositional behaviors of the european corn borer, Ostrinia nubialis (Lepidoptera: Pyralidae). Journal of Chemical Ecology 21:1315-1327. doi: https://doi. org/10.1007/BF02027564.

Caasi-Lit MT. 2006. Philippines Bt Corn and Potential Alternate Host Plants of the Asian Corn Borer. Los Baños, Laguna: SEARCA (Southeast Asian Regional Center for Graduate Study and Research in Agriculture) Biotechnology Information Center. UPLB Campus.

Calas D, Berthier A, Marion-Poll F. 2007. Do european corn borer females detect and avoid laying egss in presence of 20-hydroxyecdyson? Journal of Chemical Ecology 33:1393-1404. doi: https://doi.org/10.1007/s10886-007-9302-5.

Ceballo FA, Rejesus BM. 1983. Tryptophan and lysine supplemented artificial diet for corn borer (Ostrinia furnacalis Guenee). Philippine Entomologist 6:531-538.

Duke JA. 2012. Handbook of energy crops. Available at: http://www.hort.purdue.edu. [accessed 15 February 2018].

Grant GG, Langevin D. 1995. Oviposition deterrence, stimulation, and effect of clutch size of Choristoneura (Lepidoptera: Noctuidae) species by extract fractions of host and nonhost foliage. Environmental Entomology 24:16561663. doi: https://doi.org/10.1093/ee/24.6.1656.

Greenberg SM, Sappington TW, Legaspi BC Jr, Liu TX, Setamou M. 2001. Feeding and life history of Spodoptera exigua (Lepidoptera: Noctuidae) on different host plants. Annals of the Entomological Society of America 94:566-575. doi: https://doi. org/10.1603/0013-8746(2001)094[0566:FALH OS]2.0.CO;2.

Hartadi H, Reksohadiprodjo S, Tillman AD. 1983. Tabel Komposisi Pakan untuk Indonesia. Yogyakarta: Gadjah Mada University Press.

Hartemink AE. 2001. Biomass and nutrient accumulation of Piper aduncum and Imperata cylindrica fallows in the humid lowlands of Papua New Guinea. Forest Ecology and Management 144:19-32. doi: https://doi.org/10.1016/S03781127(00)00655-1.

Hartemink AE. 2002. Nutrient stock and nutrient cycling of follows in the humid lowlands of
Papua New Guinea. In: $7^{\text {th }}$ World Congress of Soil Science (Bangkok, 14-21 August 2002). pp. 691-691. Bangkok: Land Development, Ministry of Agriculture and Cooperatives (LDD), The Soil and Fertilizer Society of Thailand (SFST), The International Union of Soil Science (IUSS).

Head G. 2004. Adapting insect resistance management strategy for transgemic Bt crops to developing world needs. In: The 8th International Symposium on the Biosafety of Genetic Modified Organisms, (Montpellier, 26-30 September 2004). pp. 16-20. Montpellier: INRAE

Horticulture and Crop Science at The Ohio State University. 2012. Poaceae (Graminae). Available at: http://www.hcs.ohio-state.edu [accessed 11 April 2019].

Jacobs SWL. 2012. Key to classes of vascular plants in New South Wales: Family Poaceae. Available at: http://plantnet.rbgsyd.nsw.gov.au [accessed 11 April 2019].

Kojima W, Takeshi F, Momoko S, Mitsuo M, Ishikawa Y. 2010. Physiological adaptation of the Asian corn borer Ostrinia furnacalis to chemical defenses of its host plant, maize. Journal of Insect Physiology 56:1349-1355. doi: https://doi.org/10.1016/j.jinsphys.2010.04.021.

Li G, Ishikawa Y. 2004. Oviposition deterrents in larval frass of four Ostrinia species fed on an artificial diet. Journal of Chemical Ecology 30:1445-1456. doi: https://doi.org/10.1023/ B:JOEC.0000037750.64844.4b.

Nentwig W. 1998. Weedy plant species and their benefecial arthropods: potential for manipulation in field crops. In: Pickett CH, Bugg RL (Eds), Enhancing Biological Control, Habitat Management to Promote Natural Enemies of Agricultural Pest. pp. 49-71. Berkeley: University of California Press.

Nonci N, Tandiabang J, Baco D. 1996. Kehilangan hasil oleh penggerek jagung (Ostrinia furnacalis) pada berbagai stadia tanaman jagung. Hasil Penelelitian Hama/Penyakit 1995/1996. Maros: Balai Penelitian Tanaman Serealia.

Peplinski AJ, Paulsen MR, Anderson RA, Kwolek WF. 1989. Physical, chemical, and dry-milling characteristics of corn hybrids from various genotypes. Cereal Chemistry 66:117-120.

Reynolds OL, Keeping MG, Meyer JH. 2009. Silikon-augmented resistance of plants to herbivorous insects: a review. Annals of Applied Biology 155:171-186. doi: https://doi. org/10.1111/j.1744-7348.2009.00348.x.

Smith M. 2003. Public sector plant breeding and pest resistance management. in Online Proceedings 
of CAST Pest Resistance Management Symposium, Indianapolis, IN, USA, April 1011, 2003. (The Council for Agricultural Science and Technology, Washington, DC, USA, 2003). http://www.pestmanagement.info/rmworkshop/ [accessed 14 August 2017].

Soepardi G. 1986. Alang-alang (Imperata cylindrica (L.) Beauv.) and soil fertility. BIOTROP Special Publication 5:57-69.

Tabashnik BE, Carriere Y, Dennehy TJ, Morin S, Sisterson MS, Roush RT, Shelton AM, AndjianZhou Z. 2003. Insect resistance to transgenic Bt crops: Lessons from the laboratory and field. Journal of Economic Entomology 96:1031-1038. doi: https://doi.org/10.1093/jee/96.4.1031.

Tabashnik BE, Sisterson MS, Ellsworth PC, Dennehy TJ, Antilla L, Liesner L, Whitlow M, Staten RT, Fabrick JA, Unnithan GC, Yelich AJ, EllersKirk C, Harpold VS, Li X, Carrière Y. 2010. Suppressing resistance to Bt cotton with sterile insect releases. Nature Biotechnology 28:13041307. doi: https://doi.org/10.1038/nbt.1704.

Trisyono YA. 2001. Managing insect resistance to transgenic crop expressing Bacillus thuringiensis Toxins. In: Proceeding of The $2^{\text {nd }}$ Indonesian Biotechnology Conference (Yogyakarta, 2326 October 2001). Yogyakarta: Indonesian Biotechnology Consortium.
UdayagiriS, MasonCE. 1995. Hostplantsconctituents as oviposition stimulants for a generalist herbivora: European corn borer. Entomologia Experimentalis et Applicata 76:59-65. doi: https://doi.org/10.1111/j.1570-7458.1995. tb01946.x.

van Leerdam MB, Johnson KJR, Smith JW Jr. 1984. Effects of substrate physical characteristics and orientation on oviposition by Eoreuma loftini (Lepidoptera: Pyralidae). Environmental Entomology 13:800-802. doi: https://doi. org/10.1093/ee/13.3.800.

Yan F, Liang X, Zhu X. 1999. The role of DIMBOA on the feeding of Asian corn borer, Ostrinia furnacalis (Guenee) (Lepidoptera: Pyralidae). Journal of Applied Entomology 123:49-53. doi: https://doi.org/10.1046/j.14390418.1999.00304.x. 